\title{
The Contributions of ICT in Ensuring Access and Equity in the Production of Teachers in Nigeria Using Open and Distance Education
}

\author{
Charity O. Igbokwe \\ Akwa Ibom State College of Education, Afaha Nsit, Nigeria
}

\begin{abstract}
In Nigeria, open and distance education (ODE) is known to have offered access to many teachers who would have previously been denied educational opportunities based on where they live and work, poor economic conditions, social status, etc.. To this end, this paper examined the contributions of information and communications technology (ICT) in ensuring access and equity in the production of such teachers in Nigeria using ODE. This examination was based on existing data and evidence. The findings showed that most of the ODE institutions, like the National Open University of Nigeria (NOUN) and the National Teachers' Institute (NTI), operate the study centre system furnished with some ICT facilities, like computers, multi-media players, liquid crystal display (LCD) projectors, televisions, and printers, and do their registration and distribute course materials online. Notwithstanding, they still use the face-to-face mode of teaching and print technology. Some of the problems facing the use of ICTs in ODE institutions in Nigeria were discovered to include lack of knowledge and skills by some facilitators in designing and developing courses in electronic format, poverty and poor ICT penetration, poor Internet connectivity especially in rural areas, lack of computer education background by student teachers, electricity failure, low teledensity, and lack of universal access to ICTs. Consequently, it was recommended that education leaders and teacher educators should ensure that teachers who are products of ODE can competently use ICT as an enabler to optimize learning opportunities by developing teacher education programmes that use ICT-blended pedagogy to improve teaching and learning, especially in the area of curriculum delivery and assessment. In-service and pre-service courses in integrating ICTs in teaching and learning were recommended for student teachers, teachers, course facilitators, and education leaders.
\end{abstract}

Keywords: open and distance education (ODE), access, equity, information and communications technology (ICT)

\section{Introduction}

A major driving force that has directed the evolution of open and distance education (ODE) is the vision by the American visionary, Charles Wedemeyer (1978), that access to all levels of education should be widened and that distance education is a significant force in achieving that vision. Of course, widening access to all levels of education would mean changes in the way education and training programs are produced and delivered, how educational institutions are organized, and how educational resources are distributed (United Nations Educational, Scientific, and Cultural Organization (UNESCO), 2002a; 2002b). This is the major goal

Charity O. Igbokwe, Ph.D., lecturer I, Department of Early Childhood Education, Akwa Ibom State College of Education. 
of ODE. The immediate driver of this revolution is the application of information and communications technologies (ICTs) as resources for learning and transmission of information. The report of the UNESCO International Commission on Education (UNESCO, 1997) for the 21st century learning suggested that the most promising area for the use of ICTs is in the development of ODE, adding that ODE and new ICTs secure a wider access to higher education and to new social groups.

Many researchers have emphasized the promises of ICTs in distributing opportunities more wide and equitably in open and distance teacher education. For instance, Robinson (2008) reported that the use of distance education and ICTs has the potential to distribute opportunities for learning more wide and equitably across the teaching force. It can also improve the quality and variety of the resources and support available to teachers, opening up new avenues to professional development. Similarly, Jimoh (2013) is of the view that open and distance learning, together with appropriate ICTs, has the powerful potential to impact significantly on education content and delivery in teacher development in Africa. However, these researchers are of the view that if social justice is to be achieved in terms of equity of educational opportunity and services, the provision needs to be planned in ways that make it available, accessible, acceptable, and adaptable to all those desiring professional teacher development, empowering them to make choices in what and how they learn.

But, to what extent has the promises of ICTs been explored in Nigeria, for instance, in transforming ODE to achieve the goal of providing access to quality teacher professional development and equity in teacher educational opportunities? The answer to this important question, which is very central in this paper, requires the knowledge of the necessary ICT infrastructure for a third or fourth generation single-mode open and distance educational institution which uses ICTs that are interactive, electronic, and computer-based as its basis for distributing information and facilitating communication between learners and teachers as in video-conferencing, audio-conferencing, electronic mails, or most computer-based discussions. Relative to this infrastructural requirements and using available literature, a situational analysis of ODE in Nigeria was carried out to determine ICT utilization and its impact on the professional development of teachers by ODE. Thereafter, issues and challenges facing the application of ICTs in open and distance teacher education in Nigeria were identified and appropriate recommendations were made. The contributions in this paper were based on available literature. The discussion will start with clarification of some important concepts.

\section{Clarification of Keywords and Phrases}

\section{ODE}

Although distance education has developed in parallel with the evolution of technology, but the driving force that has directed the evolution of distance education is the vision by the American visionary Charles Wedemeyer that access to all levels of education should be and could be "widened" or "open" (UNESCO, 2002a). So, while open learning is a philosophy aimed at widening access and personal choice in learning (over time and place of study, curriculum content, pace, method, media, and assessment), distance education refers to the form of delivering open learning.

Moore and Kearslay (1996) defined distance education as "planned education that normally occurs in a different place from teaching and as a result requires special techniques of course design, special institutional techniques, and special methods of communication by electronic and administrative arrangement" (p. 2).

Distance education differentiates itself from face-to-face education in terms of (UNESCO, 2002a):

1. Separation of acts of teaching and learning in time and space; 
2. It is institutionalized in terms of planning, development, and delivery of teaching;

3. Normal environment is the students' home with the possibility of occasional face-to-face meetings of learners for practicals or accessing technology that is not available in their local settings;

4. Use of communication technology to deliver instructions and provide administrative services;

5. Two-way communication to ensure interaction and dialogue between learners and teachers.

The revised National Policy on Education (Federal Government of Nigeria, 2004), among other things, stated that the goal of distance education should be to provide access to quality education and equity in educational opportunities for those who otherwise would have been denied.

The merger between open learning and distance learning makes up what is known as open and distance learning. While distance learning is a system and a process that connects learners with distributed learning resources, distance education is concerned with education delivery where the acts of teaching and learning are separated in time and space (UNESCO, 2002a; 2002b). Although not strictly correct since distance education includes teaching as well as learning, but for the purpose of this paper, distance learning and distance education will be used interchangeably. Hence, Akande and Sofowora (2011) citing UNESCO (2002a) said that open and distance learning reflects both the fact that all or most of the teaching is conducted by someone removed in time and space from the learner and the mission aims to include greater dimensions of openness and flexibility whether in terms of access, curriculum, and other elements of structure. Therefore, the use of communication technology, such as digital ICTs, will facilitate the philosophy of open learning through distance education.

Open and distance learning is important because it makes education accessible and reduces cost while maintaining quality. The use of distance education makes for equality of educational opportunities and services. It also improves the quality and variety of resources and support available to learners while opening up new avenues to professional development (Jimoh, 2013).

\section{Access}

The term "access" in education typically refers to the ways in which educational institutions and policies ensure or at least strive to ensure that students have equal and equitable opportunities to take full advantage of their education. Increasing access generally requires schools to provide additional services or remove any actual or potential barriers that might prevent some students from equitable participation in certain courses or academic programs (Asia Society, n.d.).

Factors, such as race, religion, gender, sexual orientation, disability, perceived intellectual ability, past academic performance, special education status, English language ability, family income, or educational attainment levels, in addition to factors such as relative community affluence, geographical location, or social facilities, may contribute to certain students having less "access" to educational opportunities than other students.

When used in reference to education reforms, access typically refers to school strategies or policies designed to remove institutional disincentives or to provide the resources, social services, and academic support that certain students may need to succeed in school. If access is denied or left unaddressed by a school, students may struggle academically or drop out, learning gaps may compound or widen over time, students may be unable to participate in certain courses, school programs, extracurricular activities, or sports, among other undesirable outcomes (Organization for Economic Corporation and Development (OECD), 2008; Robinson, 2008). 
Important types of access that government may provide for pre-service and in-service teachers include access to high-speed Internet connections and adequate hardware (computers, laptops, and tablets) and software (particularly learning applications), so that student teachers have equitable access to the same digital and online learning opportunities regardless of their family income level, location, or ability to pay for these technologies. Hence, the major goal of distance education, as specified in the revised National Policy on Education (Federal Government of Nigeria, 2004) for Nigeria, is to provide access to quality teacher education and equality in educational opportunities for those who otherwise would have been denied.

\section{Equity}

Asia Society (n.d.) defined equity (fairness) in education to mean that personal and social circumstances, such as gender, ethnic, origin, or family background, are not obstacles to achieving educational potential (fairness) and that all individuals reach at least a basic minimum level of skills (inclusion).

Equity in education has two dimensions. The first is fairness, which basically means making sure that personal and social circumstances should not be an obstacle to achieving educational potential. The second is inclusion, in other words, ensuring a basic minimum standard of education for all, for example, ensuring that all basic education teachers have a Nigeria Certificate in Education as the minimum qualification. This is a major area of achievement of the ODE programme in Nigeria in which the National Teachers' Institute (NTI) has played a leading role.

Within the Asia-Pacific region, countries like Korea, Shanghai (China), and Japan have attended both high indicators in quality and equity. In North America, Canada is an example. The United States is below the OECD mean with regard to equity (OECD, 2008).

\section{ICT}

UNESCO (2009) defined the term "ICT" as "The system of technologies, tools, and devices that are used to transmit, process, store, create, display, share, or exchange information by electronic means".

This broad definition encompasses a wide array of technologies, such as computers and its peripherals, video, radio, television, compact disc (CD), digital video disk (DVD), telephone (mobile and fixed line), personal digital assistants (PDA), digital cameras, satellite systems, network hardware and software, as well as equipments associated with these technologies, such as video-conferencing, e-mails, Web logs (blogs), and social network (such as Facebook, Friendsters, MySpace, and Twitters). ICT or information technology (IT) stresses the role of unified technology and the integration of telecommunications (telephone lines and wireless signals) computers as well as necessary enterprise software, middleware, storage, and audio-visual systems, which enable users to access, store, transmit, and manipulate information. There are large economic incentives (huge cost savings due to elimination of the telephone network) to merge the telephone network with the computer network system using a single unified system of cabling, signal distribution, and management.

In relationship to ODE, Rao (2012) defined ICT as a group of technologies by which various support services shall be provided at different phases of student's learning life cycle. The various phases being the admission phase (programme details, fee structure, admission procedure, registration, and re-registration), the learning phase (learning schedule and programme delivery, lecture through video-conferencing, audio and video programmes, multi-media presentations, and case studies), the evaluation phase (examination schedule, internal and external assessment, examinations, improvement, valuation, revaluation, and result declaration), and the certification phases (marks/grades updates, certificate printing and issuing, and convocation schedule). 
ICT is playing a virtual role in open and distance learning to meet the requirement and expectations of learners in a large scale. Moore and Kearsley (1996) opined that it is difficult to perform the same using the traditional institution system due to its limited resources, like space and learners' resources.

\section{ICT Infrastructure in ODE}

Since in ODE, learners are remote to the institution and are in a large number, it is difficult for a learner to physically visit the institution regularly to get advice/support or services as is the case in a conventional system, just as it is equally difficult for the institutions to physically provide various services to the learner due to limited available human resources required to serve the unbounded student population. ICT becomes a major means of overcoming the limitations on both the part of the learner and the institution. The following are therefore the necessary ICT infrastructure required to effectively provide various services at different phases of a student's life cycle in a single-mode ODE, as reported by Rao (2009; 2012):

\section{Network Infrastructure}

A single-mode ODE institution requires network infrastructure at all its operational nodes (headquarters and zonal, state, and study centers) interconnected to each other through a dedicated network so that all student services can be accessed easily by all operational nodes, students and the public. The network should include adequate and standard network components that are used at gateways and other parts of structured network. The standard network components are router, network switches, and standard network cables (fibre and unshielded twisted pair (UTP)). Wireless connectivity (Wifi/Wi-max) should also be used wherever needed (Rao, 2009; 2012).

\section{Computing Infrastructure}

Standard computer hardware, such as servers (database servers, Web servers, backup/recovery servers, and application servers to host various student learners and support services) and personal computers (desktops, laptops, and notebooks) to access services, is also required in an ODE institution (Rao, 2009; 2012).

\section{Stable System and Application Software}

To develop software for various student learning and support services needed at different phases of a student's learning life cycle, system and application software is needed. In an ODE institution, software is a major infrastructure component by which various support services are provided to students and the public in a large scale. The present Web of technologies supports the development of Web-based software for various services that can be accessed anywhere and anytime. Web technologies are broadly categorized as Linux, Apacha, MySQL, and PHP (LAMP). Many learning management systems (LMS), such as Modular Object-Oriented Dynamic Learning Environment (MOODLE), are available. A LMS is a complete system that covers all phases of a student's learning life cycle (Rao, 2009; 2012).

\section{Internet Service Provider (ISP) and Internet Bandwidth}

An ODE institution needs Internet bandwidth to access Web-based student learning and support services. The amount of Internet bandwidth required depends on the number of users who access the services. The accessibility of the service of the institution will depend on the availability of Internet bandwidth reserved in a particular institution where service is hosted. An ISP is the organization that provides Internet bandwidth (Rao, 2009; 2012). 


\section{Security Infrastructure}

An ODE institution requires security infrastructure to protect the systems (servers and personal computers), software, applications, and the data that are being used to make student learning and support services available. Security infrastructure counters security attacks. The gate-way (the starting and ending point for inbound and outbound traffic) of systems needs to be protected with security devices. The standard security devices are the firewall, intrusion detection system (IDS), intrusion prevention system (IPS), antivirus software, and other monitoring systems. Security for a service should be ensured by protecting its network domain where the service is running, its system domain on which the system is hosted, and the service/application itself. Each security device should be configured with proper access control.

\section{Policy Document}

There is a need for ODE institutions to have a policy document that covers various policies that are to be enforced in the institutions. Such policies should include operational policies, security policies, and organizational policies. The policy document helps to set up the ICT infrastructure properly and to have access control. Such policy is dynamic and can be changed as the need arises (Rao, 2009; 2012).

Cognizant of ICT infrastructural and specialized skill challenges in operating an ODE institution, the open and distance learning guidelines in the Nigerian university system among other things stipulate as follows (National Universities Commission (NUC), 2009):

The open and distance learning mode shall not be applicable to academic disciplines in a university that does not have capability for that discipline. In view of the nation's present technological and infrastructural challenges, the academic disciplines which may be offered by the open and distance learning mode within the short to medium term (2009-2015) are courses in education, administration/management sciences, social sciences, arts/humanities, sciences and applied sciences. (p. 4)

For the purposes of quality assurance, the document further specified the following minimum standards on the nature and delivery of academic programmes by open and distance learning:

1. Interactive texts shall be at the heart of teaching and learning. These shall be supplemented with other resources, such as CD-ROM, DVD, or USB sticks to deliver, e-books, simulations, assessment, etc.;

2. Students should not be required to attend classes or have face-to-face contact, unless there are compelling reasons to justify it, such as examinations, periodic facilitation, and practicum;

3. Open and distance learning programmes shall be predicated on a pedagogy that is led by resources and not reliant on face-to-face intervention;

4. Students should be able to register to study anywhere in Nigeria or any part of the world with a common standard of service at any study centre;

5. The study centre system should offer both academic and social support. Study centres should act as the focal points of learning communities and have agreed standards of accommodation in facilities and equipment;

6. Collaboration between providers, e.g., in "university centres", will offer a cost-effective means of providing study centres;

7. Students should be expected to be able to have access to ICT to assist their learning. For specific programmes, functional Internet access would be required for all study centres;

8. Assessment will include continuous assessment (a minimum of one marked assignment for each 40 hours of study) as well as summative assessment, e.g., exams and portfolios that provide for validation of achievement;

9. It is expected that assessment tasks will occupy a minimum of $10 \%$ of study time. The course score should depend on both the continuous and final assessment;

10. Effective marking of assessment tasks and feedback require rapid return-A target maximum of three weeks is appropriate but ICT may allow this to be reduced. Such standards will be necessary to ensure open and distance learning 
awards have a high reputation;

11. Loading on staff may be reduced by the use of automatically marked ICT-based assignments. (NUC, 2009, p. 5)

Of course, these requirements have serious implications on ICT infrastructure and skills. Hence, Onwe (2013) reported that the National Open University of Nigeria (NOUN) is currently the only uni-mode university mandated by NUC for open and distance learning in the delivery of university education and the courses approved to be offered in the short to medium term (2009-2015) include education, administration/management sciences, social sciences, art/humanities, and science and applied sciences. Nonetheless, from available literature, it appears that presently, neither the NOUN, the NTI, nor any other institution in Nigeria involved in ODE has the adequate ICT infrastructures in standard and functional forms to run a single-mode institution, hence, they all run the dual-mode system involving both face-to-face and distance education forms.

\section{Impact of ICT in ODE in Nigeria: Situational Analysis}

Worldwide, the history of development of ODE shows that today, emphasis is on distance education and lifelong learning using the modern ICT approach either through integrated media approach, multi-site learning system, e-learning, or through virtual classroom. Other methods include written materials, interactive television/radio instruction, videos, audio tapes, and CD-ROMs to the learners. Currently, e-mails, the Web, and video-conferencing over broadband network connections are used as well. Through these methods, opportunities are provided for the learners to play back or revisit materials they have missed or do not understand. Learners can also check their understanding at the end of sections through the use of self-assessment questions. Similarly, learners can skip or skim materials with which they are already familiar, this is because they are modularized and learner-centred. Therefore, ICT has a positive impact on distance learners (Dennis, 1997; Akande \& Sofowora, 2011; Igwe, 2012).

Many educators (Akande \& Sofowora, 2011; Jimoh, 2013) have lamented the reality in the nation's university education scenario which is characterized by perennial mismatch between the demand and supply side of the access equation. The current situation is that there are thousands of young qualified candidates seeking university admission who cannot be absorbed into the nation's universities. The Nation Open University Bill was approved on 20th April, 1993, to provide access to higher education for those facing physical challenge, financial constraint, and geographical remoteness, for those less privileged, for those who need not secure admission into full time residential programme because of the nature of their employment or family circumstances, or for those who are not catered for by the existing university (Akande \& Sofowora, 2011). Yet, according to the policy document (Federal Government of Nigeria, 2004), the goals of ODE are to provide access to quality education and equity in educational opportunities for those who otherwise would have been denied.

Unfortunately, an analysis of the state of open and distance learning in the Nigerian university system reveals that "There are only about six universities which may be regarded as dual-mode universities with limited capacity to deliver degree programmes by the open and distance learning in addition to the conventional face-to-face mode" (NUC, 2009, p. 2).

The accredited distance learning institutions in Nigeria are: (a) the NOUN; (b) the Centre for Distance Learning (CDL), Obafemi Awolowo University; (c) the Distance Learning Institute (DLI) of the University of Lagos; (d) the Distance Learning Centre (DLC) of the University of Lagos; and (e) the NTI, Kaduna (Onwe, 2013). 
Among these universities, the NOUN is currently the only uni-mode university mandated for open and distance learning in the delivery of university education.

But, how has ICT contributed in the achievement of the objectives of setting up open and distance learning in these institutions with particular reference to teacher education programmes? Akande and Sofowora (2011) reported that the National Open University which started with teacher preparation programmes among others has, since its inception, been employing integrated media and multi-media technologies in teaching, using correspondence education closely supplemented by lectures, tutorials, and counseling services organized through a network of local study centers called multi-site or multi-campus method. As noted earlier, NOUN is the first fully fledged university that operates in an exclusively open and distance learning mode of education in Nigeria. The university focuses mainly on a distance teaching and learning system, and delivers its course materials via print in conjunction with ICT formats, like CD-ROMs and on the basis of self-learning. NOUN currently has 30 study centres, which are stratified into the six geopolitical zones of the nation. Students' enrolment capacity is projected at about 50,000 students. This figure is the reason to conclude that the open and distance learning mode of education holds a great prospect as it increases capacity in the educational sector. Its greatest challenge is power generation and high cost of access to ICT facilities by both students and staff.

Other institutions that have used new ICTs to widen access to teacher education programmes through ODE are University of Lagos, University of Abuja, Abia State University, Imo State University, University of Ibadan, the NTI, and Obafemi Awolowo University.

Akande and Sofowora (2011) reported that Obafemi Awolowo University has integrated ICTs into distance learning and into every aspect of academics and administration using the new ICT strategic plan for resolving the challenges of quality education through distance learning programmes. The flexibility and accessibility enabled by ICT led to the emergence of open distance learning in Obafemi Awolowo University (Ile-Ife) through virtual learning, electronic medium, and integrated media techniques for which the university was known and acclaimed as the foremost ICT university in Nigeria. As a result, the university has set the pace in developing a strong ICT-based program for out of school youths and adult learners in remote areas all over the country using the multi-site technology via interactive radio/televised instruction, ICT-based simulations, and e-learning platforms using the LMS called Academic Blackboard.

In the same vein, it is necessary to note that the NTI was the first institution specifically established by the Federal Government to provide distance education courses designed to upgrade under-qualified and unqualified teachers. The NTI also introduced the Nigerian Certificate in Education by distance learning in 1990 (Commonwealth of Learning International, 2001). Other certificate programmes run by the Institute on Distance Learning are Advanced Diploma in Education and Postgraduate Diploma in Education. Ekpunobi (2014) reported that the institute has finalized arrangement to be affiliated with the NOUN to run degree programme in education by January, 2015.

The NTI operates the study centre system furnished with some ICT facilities, like computers, multi-media players, LCD projectors, televisions, and printers, and does its registration and distributes course materials online. Notwithstanding, it still uses the face-to-face mode of teaching and print technology. Ekpunobi (2014) reported that other ICT initiatives used by the institute include the NTI Radio Broadcast, which provides professional support to teachers in the classroom. This transmission which began in 2008 has now included weekends when more teachers will have time to listen. Through the ODE facilitated by ICT, the NTI has graduated more than 300,000 teachers at the teachers Grade II and National Certificate in Education levels. 
Generally, the practice of ODE in teacher preparation in Nigeria takes various forms, which include correspondence study education, distance learning (sandwich programmes), part-time teacher training programme, open university, weekend programs, adult literacy education programmes, NTI, and e-learning. These have provided student teachers with useful knowledge, skills, attributes, and abilities.

From the above situational analysis, it is clear that although ICT is not yet fully integrated to teacher education by ODE in Nigeria, it has made some positive impacts to the extent of its use, namely:

1. It has increased equitable access to teacher education programmes for people in remote areas and to other disadvantaged groups by providing them with quality educational opportunities using multi-site learning;

2. It has increased people's access to teacher education. Many people who would have found it impossible to attend conventional high institutions benefit from ODE. Nigeria can now boast of capable and competent teachers working in its education sector, improvement in the quantity and quality and overall capacity of education managers, as well as school administrators necessary to lead the nation's educational system (Dennis, 1997).

NUC (2009), Akande and Sofowora (2011), and Jimoh (2013) have lamented that even in the face of obviously and widely acknowledged perennial inadequacies of the conventional face-to-face mode in meeting the higher educational aspirations of a large number of Nigerians, especially in the university sub-sector, and despite the potentials of ODE for equitable access to teacher education in Nigeria, there is still a mismatch between policy and practice in ODE. This is possibly because of the heavy funding, ICT skills, and infrastructural requirements for operating a complete single-mode third or fourth generation ODE institution.

All stakeholders agree that the practice of distance learning by these dual-mode universities is far below acceptable best practice and that at best, they are in transition from the running of part-time/sandwich courses to distance learning.

So, the pertinent question is "Has ICT lived up to its promises?". This is probably true as far as it holds promises for incremental improvement, including an increased access and quality of the learning experience - an improvement whose importance should not be underestimated. As for radical innovation, the answer is "Not yet". In line with this view, Igwe (2012) opined that so far, ICT has induced a quiet rather than a radical revolution of ODE, particularly in Nigeria.

\section{Issues and Challenges Facing the Application of ICTs to Open and Distance Teacher Education in Nigeria}

The Federal Government of Nigeria developed a plan for a decade of distance education in Nigeria, which among others has the following objectives in mind (Association for the Development of Education in Africa (ADEA), 2002):

1. Establishment of a solid institutional framework for distance education in Nigeria, following a carefully conducted needs assessment studies;

2. Provision of higher education to a minimum of one million qualified candidates through the distance and open learning modes involving public and private sector participation, in areas of high human resource needs;

3. Training of 20,000 distance education operators including course writers, support service providers, managers, instructional designers, and technicians;

4. Establishment of a virile ICT-driven distance education delivery system. 
Onwe (2013) reported that the NUC observes, however, that a critical appraisal of the scope of the practice of open and distance learning at any level of education in Nigeria against the backdrop of the long-standing recognition of its potential for increasing access to education reveals some mismatch between policy and practice. For instance, available records indicate that the NOUN is currently the only uni-mode university mandated for open and distance learning in the delivery of university education (NUC, 2009).

Onwe (2013) remarked that, though various sub-Saharan African countries have in general been found experimenting with the use of third and fourth generation technologies, such experiments appear to be limited to few institutions and ICTs with limited scope. He disclosed that the use of ICTs in teaching and learning in sub-Saharan Africa is seriously hampered by lack of expertise, lack of infrastructure, and a largely technologically illiterate user group. Finally, the sub-Saharan African countries need to embrace forward looking policies on new generation applications of ICT in teaching and learning.

Hence, Akande and Sofowora (2011) reported that the highest factor affecting ICT usage among distance learners who enrolled for the Bachelor of Education programs at the Obafemi Awolowo University (Ile-Ife), was lack of skills. Others include poor ICT infrastructure in the rural areas and epileptic power supply which have negatively affected the development and integration of ICT in distance and open teacher education. They asserted that poor funding of education by government, facilitators' lack of knowledge and skills in designing and delivering courses in electronic format, poverty and low level of computer literacy among Nigerians, as other factors, affect ICT usage among distant teacher education learners. Similarly, Adebayo (2007) reported that a major challenge to open and distance learning programme delivery is low teledensity. It was observed that access to unhindered use of ICT tools, such as telephones and the Internet, has been very low. Jimoh (2013) remarked that despite the advent of the Global System of Mobile (GSM) telecommunications, the use of ICT resources for professional teacher development purposes in general and open and distance learning in particular is still very low. He further observed that because most of the open and distance learning students have no computer education background, they suffer from technophobia to the extent that some of them go to the extent of hiring experts at a cost to fill their admission forms, register and complete other documents meant for them to fill online. He was concerned that even some few who have access to computers do not know how to use it and take full advantage of its usage.

\section{Conclusion and Recommendations}

This paper discussed the necessary ICT infrastructural requirement and the minimum standard stipulation by the NUC for any ODE institution to achieve access and equity in professional teacher development. The situational analysis of the contributions of ICT in ensuring access and equity in the production of teachers reveals that although ICT is yet to be fully integrated to distance teacher education on a large scale in Nigeria, there is empirical evidence to show the positive impact it made in the institutions where it has been integrated, especially in terms of reaching out to population in remote areas and to other disadvantaged groups by providing them with quality educational opportunities using the multi-site learning systems. The major hindrances militating against the use of ICT to achieve equitable access in professional teacher education using ODE are lack of appropriate ICT infrastructure and lack of ICT knowledge and skills on the part of course facilitators and the students. In view of the findings, the following are recommended:

1. Since in Nigeria, universal access to ICTs represents a perplexing challenge, when designing new distance teacher education systems or improving existing delivery systems, planners should design the delivery 
system based on the practical realities derived from the level of access to different ICTs. For example, print-based form of distance education delivery should be used where universal access to basic telecommunications infrastructure is poor. Sustainable alternatives to sophisticated digital ICTs delivery systems should be put in place to guard against system failure;

2. No national education system can rise above the teachers' quality, hence, facilitators of open and distance learning should be well trained to improve their effectiveness and efficiency in integrating ICTs in developing course materials meant for professional teacher development in ODE institutions.

To prepare toward fulfilling the promises of ICT as immediate driver of ODE in guaranteeing equitable access to teacher education for all socio-cultural groups, using the Malaysian model (Muniandy, Phing, \& Rasalingam, 2007; Shadaruddin, 2005), government should sufficiently provide the necessary funds, electricity power supply, and ICT infrastructure in open and distance learning institutions and prepare the next generation of teachers in Nigeria in line with the following standards for implementing ICT in teacher education programmes:

1. ICT curriculum for pre-service teachers in Nigerian public universities should cover the components shown in Table 1.

Table 1

Components of ICT Curriculum for Pre-service Teachers in Nigerian Public Universities

\begin{tabular}{|c|c|}
\hline $\begin{array}{l}\text { Application practice and } \\
\text { tutorial }\end{array}$ & $\begin{array}{l}\text { hotography; desktop publishing; presentation tools; spreadsheet; database; e-portfolio; Website and } \\
\text { etworking; evaluation of Website and search engine; instructional media; overhead projector and } \\
\text { ansparency; chat and scrapbook; e-learning; and presentation }\end{array}$ \\
\hline IC & TT in education; computers in education; e-learning; emerging technology; multi-media in education \\
\hline Telecc & $\begin{array}{l}\text { Introduction to telecommunication; Web sear } \\
\text { remote access file transfer and e-mail; deskt } \\
\text { learning; network technology; topology and wir }\end{array}$ \\
\hline & Educational information agencies \\
\hline $\begin{array}{l}\text { Educ } \\
\text { instru }\end{array}$ & $\begin{array}{l}\text { Introduction to educational technology; introduction to instructional technology; learning theories; } \\
\text { communication in education; instructional design; instructional design models; instructional systems; } \\
\text { instructional media; graphics in education; projected media; overhead projector and transparency; } \\
\text { audio in education; video in education; photography in education; } 20 \text { and } 30 \text { materials in education; } \\
\text { and presentation skills }\end{array}$ \\
\hline
\end{tabular}

2. Educational leaders and teacher educators should ensure that future teachers can competently use ICT as an enabler to optimize learning opportunities by developing teacher education programmes that emphasize ICT-blended pedagogy to improve teaching and learning. To achieve this, the following teacher education programmes should be mounted for pre-service teachers, in-service teachers, principals, and head teachers:

(a) A 4-year bachelor of teacher degree programme for pre-service teachers. A compulsory course content of this programme should include "Technology in Teaching and Learning" to enable student teachers acquire the knowledge and skills of educational technology and educational media. Their respective subject majors should also include computer-aided instruction to enhance their basic ICT knowledge and skills to produce and organize ICT materials and multi-media resources in their particular areas of study. The curriculum delivery should use ICT as a tool to learn by causing students to access information and source for materials on-line through independent student learning. Teacher educators on this programme should be able to integrate ICT in the teaching and learning process. The digital library concept should also be made an integral component of the programme. Assignments given to students should require students to use ICTs in their project-based learning, 
such as accessing information from the Internet, communicating ideas using ICT, and using ICT applications to solve problems and create projects;

(b) A smart teacher training course for in-service teachers. The smart teacher course is for training teachers in integrating ICT in teaching and learning and adapting new pedagogies. The course could be a 1-Year Specialist Training Certificate Course or a 14-week professional development programme. The 1-Year Specialist Training Certificate Course should be offered in the area of ICT in education and designed for primary school teachers with a minimum of three years teaching experience. The course enhances participants' ICT competencies by increasing their knowledge, skills, and values in using ICT in education with emphasis on practical ideas and sound pedagogical concepts. The 14-week professional development programme should be an in-service course in various fields including ICT in education. The ICT course should cover knowledge and skills on computer hardware, software, networking, multi-media, basic programming, Web development, the Internet, and integration of ICT in teaching and learning. Teachers who participate in this course should become leaders and coordinators in implementing ICT in their schools;

(c) An ICT leadership development programme for principals and head teachers. Principals and head teachers should be given training in ICT knowledge and skills to enable them lead and manage their schools as ICT leaders also. Such training programme should include basic computer knowledge, effective management with ICT, and strategic ICT leadership courses. Courses that will enable such school leaders to understand the capacities of new technologies as well as to practice instructional and distributed leadership to engage in-service teachers are Instructional Design Models, Instructional Systems, Instructional Media, Graphics in Education, Projected Media, Overhead Projector and Transparency, Audio in Education, Video in Education, Photography in Education, and Presentation Skills.

3. Government should connect schools nationwide to access information and content about teaching and learning, management, and assessment. This requires the development of a repository and directory of shared digital content and resources, with funding from government and managed by the Ministry of Education.

\section{References}

Adebayo, A. M. (2007). Open and distance learning in South/West geopolitical zone (Unpublished Ph.D. thesis, University of Ado-Ekiti).

Akande J. O., \& Sofowora, O. A. (2011). Globalization, information and communication technologies (ICTs) and open/distance learning in Nigeria: Trends, issues and solution. Turkish Online Journal of Distance Education, 12(3), 1-11.

Asia Society. (n.d.). Equity and quality in education. Retrieved from http://asiasociety.org/education/learning-world/equity-andquality-education

Association for the Development of Education in Africa (ADEA). (2002, February). Distance education and open learning in sub-Saharan Africa: A literature survey on policy and practice (A report of the working group on Distance Education and Open Learning). Retrieved October 29, 2014, from http://www.col.org/PublicationDocuments/pub_02DEinSSA_Literature Survey.pdf/

Commonwealth of Learning International. (2001). Building capacity to deliver distance education in Nigeria's Federal University System (Report prepared for the World Bank). Retrieved April 26, 2006, from http://siteresources.worldbank.org/NIGERIA EXTN/Resources/capacity_de.pdf

Dennis, N. (1997, July 18). Schools ponder new global landscape. Science, p. 277.

Ekpunobi, E. N. (2014, August 18-23). National officers' reports. Report presented at The 55th Annual Conference of Science Teachers' Association of Nigeria (pp. 18-19). Asaba: National Teachers' Institute.

Federal Government of Nigeria. (2004). National policy on education. Lagos: Government Press.

Igwe, D. S. (2012). The roles of ICT development in open and distance education: Achievements, prospects and challenges. African Journal of Teacher Eduction, 2(2). Retrieved from https://journal.lib.uoguelph.ca/index.php/ajote/article/view/1827 
Jimoh, M. (2013). An appraisal of the open and distance learning programme in Nigeria. Journal of Education and Practice, 4(3), $1-8$.

Moore, M. G., \& Kearsley, G. (1996). Distance education: A systems view. Boston, M.A.: Wadsworth Publishing Company.

Muniandy, B., Phing, T. P., \& Rasalingam, R. R. (2007). Information and communication technology (ICT) training curriculum for pre-service teachers in Malaysian public univeristies: Challenges in preparing next generation of teachers. In C. Crawford et al. (Eds.), Proceedings of Society for Information Technology and Teacher Education International Conference (pp. 3107-3114). Chesapeake, V.A.: AACE.

National Universities Commission (NUC). (2009). Revised guideline for open and distance learning in Nigerian universities. Retrieved October 29, 2014, from http://www.nuc.edu.ng/nucsite/File/ODL\%20REVISED\%20GUIDELINES\%20FOR\%20 NIGERIAN\%20UNIVERSITIES.pdf

Ololube, N. P., Ubogu, A. E., \& Ossai, A. G. (2006, September 13-15). ICT and distance education in Nigeria: A review of literature and accounts. In Proceedings of The 2nd International Open and Distance Learning (IODL) Symposium (pp. 643-655), Eskisehir, Turkey.

Onwe, O. J. (2013). Policies and practices of open and distance learning models in the sub-Saharan African countries: A literature survey. American International Journal of Contemporary Research, 3(8), 122-135.

Organization for Economic Corporation and Development (OECD). (2003). New challenges for educational research. Paris: OECD.

OECD. (2008). Policy brief: Ten steps to equity in education. Paris: OECD.

Rao, M. M. (2009). Web-enabled user support services system in distance learning. Proceedings of The International Conference on Interactive Services: Information Technology, Culture and Human (ICIS, Vol. 1, pp. 86-90), Seoul, Korea.

Rao, M. M. (2012). ICT in open and distance learning: Issues and challenges. Retrieved October 29, 2014, from http://wikieducator.org/images/4/49/A._Murali_M_Rao.pdf

Robinson, B. (2008). Using distance education and ICT to improve access, equity and quality in rural teachers' professional development in western China (EU-China Gansu Education Project (ALA/CHN/98/4)). Nottingham, U.K.: UNESCO Centre for Comprehensive Research, University of Nottingham.

Shadaruddin, A. M. (2005). The next generation of teachers: The Malaysian perspective. Paper presented at The 13th UNSECO-APEID International Conference on Education and World Bank-KERIS High Level Seminar on ICT in Education.

United Nations Educational, Scientific, and Cultural Organization (UNESCO). (1997). The treasure within: Report to UNESCO of the International Commission on Education for the twenty-first century. Retrieved October 29, 2014, from http://www.unesco.org/education/pdf/15_62.pdf

UNESCO. (2002a). Information and communication technologies in distance education: Specialized training course. UNESCO Institute for Information Technologies in Education.

UNESCO. (2002b). ICTs in teacher education: A planning guide. Retrieved January 20, 2009, from http://unescodoc.unesco.org/ images/0012/0012/001295/129533e.pdf

UNESCO. (2009). The regional workshop on integration in education in the SEAMEO member countries. Retrieved October 29 , 2014, from http://www.rihed.seameo.org/wp-content/uploads/2012/04/2009-09.pdf

Wedemeyer, C. A. (1978). Independent study. In A. S. Knowles (Ed.), The international encyclopedia of higher education. San Francisco, C.A.: Josey-Ben Publishers. 